\title{
The Effectiveness of Criminal Sanctions Against the Narcotics Criminals
}

\author{
Dian Andriani Ratna Dewi ${ }^{1}$, Zudan Arief Fakrulloh ${ }^{2}$ \\ University of Borobudur ${ }^{1,2}$ \\ \{dianunborr@gmail.com¹, cclsis@yahoo.com²
}

\begin{abstract}
The problem of narcotics abuse in Indonesia is now very concerning. The applied criminal sanctions have not been able to inhibit the rate of narcotics abuse in Indonesia. This paper will present the effectiveness of criminal sanctions for narcotics offenders. Through a qualitative approach using the normative juridical method, it was found that the effectiveness of sanctions against the perpetrators of criminal acts of narcotics abuse was not optimal and had a deterrent effect so that narcotics abuse still occurred in the community. Therefore, it requires the participation of all elements of society as well as law enforcement officials to socialize and involve public participation in handling narcotics abuse. The synergy of law enforcement officers and the community is more effective than relying on criminal sanctions alone.
\end{abstract}

Keywords: Effectivity; Criminal Code; Narcotics

\section{Introduction}

Indonesia is a state of law. Whatever violations or disputes that occur in Indonesia must be resolved legally. [1] Actions that are following or in line with the prevailing laws and regulations are not a problem and hence do not need to be questioned anymore. But ironically, sometimes acts that are not following the rule of law are not questioned because of matters of interest. Effective enforcement of criminal law sanctions against narcotics crime perpetrators is highly expected by the community, especially by people who are classified as economically weak, because narcotics crimes always harm victims, both health victims and economic victims, which of course will harm the community as a whole. Narcotics crimes do not only affect generations at a certain age but will attack all age levels, especially at productive ages.

The problem of narcotics abuse in Indonesia is now very concerning. [2] Indonesia is currently a drug emergency. The National Narcotics Agency (BNN) noted that the number of drug abusers in the country reached 3.5 million in 2017. Nearly 1 million of them have even become addicts. The manufacture, smuggling, and abuse of narcotics continues and grows in Indonesia. This creates several negative impacts covering the economy, health, social, and youth.

Increased supervision and control as an effort to prevent and eradicate drug abuse and trafficking is urgently needed because crimes in this field are increasingly developing both in terms of quality and quantity. Various kinds of media have been used to appeal to the public about the dangers of drugs, starting from television, the internet, posters, and so on 
Narcotics have been troubling our Indonesian society because the effects of these substances that are consumed incorrectly and excessively by their users would have fatal consequences, can also lead to death for the users. The negative impact besides death, drugs will damage the nervous system for its users so that it is not uncommon for addicts to have their nervous system disturbed.

But with the threat that drug addicts will feel, most addicts ignore it which will endanger their safety. They just love to be friends with these forbidden objects, for them, drugs are friends without souls who have the power to help them when they need them.

The cases of drug addicts from year to year are increasing, most of the users are successful people who have excess money so that getting drugs is not difficult. However, what is even worse is that there are cases of drug addicts among teenagers. This is a concern for parents, teachers, and other parties, they are worried about it because if the successors of this nation are mostly drug addicts, the future of this nation will be bleak. Therefore, it is necessary to have the correct socialization about drugs and effective efforts to prevent drug users so that it is not rampant.

In this case, the government of the Republic of Indonesia to eradicate narcotics has made very rapid efforts, this can be seen from the renewal of the Narcotics Law No. 22 of 1997 to Law No. 35 of 2009 in which the sanction is heavier so that more deterring drug abuse offenders. From the report on the development of the world drug situation in 2014, it is known that the estimated number of drug users in 2012 is between 162 million and 324 million people or around $3.5 \%-7 \%$. [3]

The comparison of the prevalence estimated in $2012(3.5 \%-7 \%)$ with the estimation in 2010 which was in the range of $3.5 \%-5.7 \%$ shows that the trend of the prevalence of drug abuse is relatively stable. Law enforcement against narcotics crime has been carried out by law enforcement officials and many judges have received decisions in court proceedings. It is hoped that law enforcement can act as an antidote to the widespread circulation of narcotics trafficking, but in reality, the more intensive law enforcement is carried out, the more the narcotics trafficking will also increase.

The imposition of the death penalty for drug dealers or traffickers under the criminal code of the Republic of Indonesia, especially in law Number 35 of 2009 concerning Narcotics. Another strong reason why the death penalty is still enforced is that drug dealers are suspected of being able to massively destroy the character of a generation of the nation's children to become drug addicts, which can affect their physical and mental health. Therefore, drug crime is considered an extraordinary crime.

Currently, the problem and drug trafficking in Indonesia have reached an alarming point. It is said to be worrying because drug addicts have penetrated widely both in the educational environment, the work environment, students, teenagers, and residential areas in rural and urban areas. With the number of drug abusers reaching 5.1 million. In 2006, it was estimated that it reached 2.3 million people, or the equivalent of 1.5 percent of Indonesia's population (at that time). The National Narcotics Agency (BNN) suspects that educational centers, such as schools, colleges, or colleges, are fertile ground for drug trafficking. Apart from having a middle and upper economy, residents of schools or colleges (youth category) also often follow an exaggerated lifestyle. Drugs are considered to be part of such a lifestyle.

The dangers of abuse are not only limited to addicts but can have further consequences, namely disruption to the order of community life which can have disastrous consequences for the nation, thus formulating the problem, namely: Description of current drug abuse and the effectiveness of criminal sanctions and government efforts in overcoming it. 


\section{Method}

The method used to research this paper uses a qualitative approach with the juridicalnormative method.[4] Data collection was carried out using documents related to the research topic and supported by literature related to the issues raised. The prescriptive analysis is used to present the collected data so that it can be described comprehensively..[5]

\section{Discussion}

Criminal sanction is a punishment for cause and effect because it is the case and the effect is the law, the person who is affected will get a penalty, either going to prison or other punishment from the authorities. Criminal sanctions are a type of sanction that is aggrieved in nature that is threatened or imposed on an act or perpetrator of a criminal act or criminal act that can interfere or endanger legal interests. Criminal sanctions are a guarantor to rehabilitate the behavior of the perpetrators of these crimes, but it is not uncommon that criminal sanctions are created as a threat to human freedom itself. Criminal is suffering or sorrow that is deliberately inflicted upon a person who commits an act that meets certain elements of conditions. Criminal is a reaction to the offense, and this is in the form of sorrow that the State deliberately bestows on the offender.[7] The purpose of punishment is to prevent the committing of crimes in the future, the purpose of holding a punishment is needed to find out the legal nature of the crime. that in the context, said Hugo De Groot "malim pasisionis propter malum actionis", namely evil suffering befell due to evil deeds. Based on this opinion, it appears that there is a conflict regarding the purpose of punishment, namely between those who view crime as a means of retaliation or absolute theory and those who argue that crime has a positive purpose or objective theory, as well as a view that combines the two objectives of punishment. Goal theory as teleological theories and combined theories are referred to as integrative views in the purpose of the punishment which assume that punishment has a plural purpose, which is a combination of utilitarian views which state that the purpose of punishment must have proven beneficial consequences, justice must not be through the imposition of suffering which deserves to be received to suffer itself, for example, that said criminal suffering must not exceed the reward that the perpetrator of the criminal offense deserves.[8]

Criminal action is a basic definition in criminal law. Criminal action is a juridical meaning as it is to provide a definition or meaning of a legal term, so it is not an easy thing to provide a definition or understanding of the term criminal act. The discussion of criminal law is intended to understand the meaning of crime as a sanction for offenses, while punishment is related to the basics of justifying criminal imposition and theories about the purpose of punishment. It should be stated here that criminal is a juridical term that has a special meaning as a translation of the Dutch language "straf" which can be interpreted as "punishment". Criminal action is a juridical definition, in contrast to the term "evil deed" or "crime" (crime or Verbrechen or misdaad) which are defined criminologically and psychologically. Regarding the content of the definition of a crime, there is no unified opinion among scholars.

As a general description, the juridical definition of a crime or criminal act is "an act that is prohibited by law and the violation is subject to sanctions", then criminologically a crime or criminal act is "an act that violates the norms prevailing in society and gets negative reactions from society, and psychologically a crime or crime is "abnormal human action that is against 
the law, which is caused by psychological factors from the perpetrator of the act. Lawmakers have used the word "strafbaarfeit" to replace the term criminal act in the Criminal Code (KUHP) without explaining what is meant by the word strafbaarfeit so that various opinions arise in the doctrine of what exactly is meant. with the strafbaarfeit. "Strafbaarfeit is a person's behavior (menselijke gedraging) formulated in wet, which is against the law, which deserves to be convicted (strafwaardig) and carried out by mistake".[9]

If "straf" means "punishment" then strafrecht should mean punishments. Furthermore, Moeljotno said that "punished" means "being punished" in both criminal law and civil law. Punishment is the result or result of the application of the law, which has a broader meaning than punishment because it also includes judges' decisions in the field of civil law. According to Sudarto, that "punishment" comes from the word "law", so it can be interpreted as "establishing the law" or "deciding about the law" (berechten). Establishing law for an event does not only concern the field of criminal law, but also civil law. Criminal is suffering that is deliberately inflicted upon a person who commits an act that meets certain conditions. Crime is a reaction to the offense, and this is a form of sorrow that the state deliberately inflicts on the offender. Criminal means the imposition of suffering by the state on a person who has been convicted of a crime. By mentioning other means the punishment must be [10] :

a. Contains suffering or other unpleasant consequences;

b. Is imposed on someone who has or is suspected of having committed a criminal act;

c. Is subject to a criminal offense that violates the provisions of the law;

d. Conducted on purpose by other than the perpetrator of a criminal act;

e. Dropped and executed by the authorities under the provisions of a legal system that is violated by the criminal act.

Imposition of the Death Penalty in Law No. 35/2009 on Narcotics: In Law No. 35 of 2009 concerning narcotics (hereinafter referred to as the Narcotics Law 2009), basically classifies the criminal offender (delict) of narcotics abuse into 2 (two), namely: the perpetrator of a criminal offense who is a user (Articles 116, 121 and 127) and not a user narcotics (Articles $112,113,114,119$ and 129), the status of narcotics users can be further divided into 2 (two), namely users to be given to others (Articles 116 and 121) and narcotics users for themselves (Article 127). What is meant by the use of narcotics for himself is the use of narcotics by a person without undergoing the supervision of a doctor. If the person concerned suffers and then suffers from addiction then he/she must undergo rehabilitation, both medically and socially, and the treatment and rehabilitation period will be counted as the period of serving the sentence, meanwhile, the narcotics offender who is not a user is classified again into 4 (four). ), namely: owner (Article 111 and 112), processor (Article 113), carrier and carrier (Article 114 and 119), and dealer (Article 129). [11]

To prevent and eradicate the abuse and illicit trafficking of narcotics which are very detrimental and endanger the life of the people, the nation, a Regulation of Article 60 of Law Number 22 of 1997 concerning Narcotics was made, which was updated in Law Number 35 of 2009 concerning Narcotics, [12] The legislation is also expected to have a deterrent effect on perpetrators by taking into account the sanctions set by lawmakers and providing certainty.

If people base criminal law on the concept of social protection / social defense, then the next task is to develop it as rationally as possible. Maximum results should be achieved at minimum costs to society and minimum suffering to individuals. In such a task, one must rely on the results of scientific research on the causes of crime and the effectiveness of various sanctions.[13]

Law Number 35 of 2009 concerning Narcotics requires comprehensive socialization supported by complete government regulations. Definition of Narcotics Abuse Article 1 
paragraph (15) of Law Number 35 of 2009 concerning Narcotics does not provide a clear explanation of the term abuse. The application of criminal sanctions against the perpetrators of criminal acts of narcotics abuse is not optimal, so there are still many violations and abuse of narcotics in the community. Therefore, it requires community participation and cooperative action from all elements of society in eradicating narcotics in Indonesia.

\section{Conclusion}

Law enforcement against crimes in Indonesia, especially in terms of punishment, should refer to the legal norm approach which is to foster criminals by providing guidance in prisons, thereby improving the convicts in those prisons. The effectiveness of sanctions against the perpetrators of criminal acts of narcotics abuse is not optimal and has a deterrent effect so that narcotics abuse still occurs in the community. Therefore, it requires the participation of all elements of society as well as law enforcement officials to socialize and involve public participation in handling narcotics abuse. The synergy of law enforcement officers and the community is more effective than relying on criminal sanctions alone.

\section{References}

[1] G. Supramono, Indonesian Narcotics Law. Jakarta: Djambatan, 2004.

[2] D. Hawari, Narcotics and Addictive Substances Abuse. Jakarta: Balai Penerbit FKUI, 1991.

[3] Moeljatno, Principles of Criminal Law. Jakarta: Bina Aksara, 1993.

[4] J. Ibrahim, "Normative Legal Research Theory and Method," Bayu Media, Malang, 2006.

[5] M. H. Dr. johnny ibrahim,SH., Normative Legal Research Theory \& Methodology. 2006.

[6] T. Andrisman, Principles and Basic Rules of Indonesian Criminal Law. Bandar Lampung: Unila, 2009.

[7] Irfani, "Corruption as an Extraordinary Crime," NASPA J., vol. 42, no. 1, 2017.

[8] i-lib Perpustakaan UGM, "Terrorism in the perspective of criminal law," Jurnal i-lib UGM. 2003.

[9] Muladi and B. N. Arief, Criminal Law Theories and Policies. Bandung: Alumni, 2005.

[10] W. Q. NABILAH, "Repetition of Crime," Surabaya, 2017.

[11] M. Asyharudddin, B. Badaru, and M. K. Hidjaz, "Analysis of Criminal Sanctions Against Narcotics Criminal Actors," Pleno Jure, vol. 9, no. 1, pp. 58-71, 2020, doi: 10.37541/plenojure.v9i1.390.

[12] M. I. R. Bangsawan, Implementation of Destruction of Narcotics Evidence. 2019.

[13] B. N. Arief, Interest of Criminal Law Policies. Bandung: Citra Aditya Bakti, 2005. 